\title{
Padaczka w chorobach mitochondrialnych
}

\author{
Marta Zawadzka, Agata Knurowska, Damian Palus, Piotr Stogowski, \\ Karolina Anuszkiewicz, Maria Mazurkiewicz-Bełdzińska \\ Klinika Neurologii Rozwojowej Katedry Neurologii Gdańskiego Uniwersytetu Medycznego
}

\begin{abstract}
STRESZCZENIE
Choroby mitochondrialne (MD, mitochondrial diseases) to jedne z najczęstszych chorób genetycznych. Pierwsze objawy MD mogą się pojawić zarówno w wieku wczesnodziecięcym, jak i podeszłym. Dotyczą one przede wszystkim tkanek i układów o wysokim zapotrzebowaniu energetycznym — mięśni szkieletowych i układu nerwowego. Do najczęstszych objawów neurologicznych należy między innymi padaczka, która może być jedynym objawem choroby mitochondrialnej lub jednym z wielu objawów. Częstość występowania padaczki mitochondrialnej zależy od rodzaju stwierdzanej mutacji i jest wyższa u dzieci i młodzieży niż u dorosłych. Podejmując się leczenia padaczki u chorego z MD, należy unikać stosowania leków o wysokim potencjale toksyczności dla mitochondriów, w szczególności preparatów kwasu walproinowego.
\end{abstract}

Polski Przegląd Neurologiczny 2019; 15 (4), 237-242

Słowa kluczowe: padaczka, choroby mitochondrialne

\section{WPROWADZENIE}

Choroby mitochondrialne (MD, mitochondrial diseases) to jedne z najczęstszych chorób genetycznych. Przynajmniej 1 na 4300 osób jest nosicielem patogennej mutacji i choruje lub jest obarczona ryzykiem zachorowania na MD [1]. Choroby te są spowodowane mutacjami w genomie mitochondrialnym lub mutacjami w jądrowym DNA kodującym białka niezbędne do prawidłowego funkcjonowania mitochondriów. Jest to heterogenna grupa chorób, które często mają charakter wieloukładowy. Objawy mogą się pojawić zarówno w wieku wczesnodziecięcym, jak i podeszłym, począwszy od ciężkiej kwasicy mleczanowej w okresie noworodkowym, skończywszy na dyskretnych deficytach neurologicznych w wieku dorosłym. Dotyczą one przede wszystkim tkanek i układów o wysokim zapotrzebowaniu energetycznym mięśni szkieletowych i układu nerwowego. Do najczęstszych objawów neurologicznych należą: opóźnienie rozwoju psychoruchowego i/lub jego regres, napady padaczkowe, epizody udaropo- dobne, migrena, mioklonie, objawy piramidowe i pozapiramidowe, ślepota korowa, zanik nerwu wzrokowego, głuchota czy neuropatia [2].

\section{PADACZKA MITOCHONDRIALNA}

Padaczka mitochondrialna (ME, mitochondrial epilepsy) może być jedynym objawem MD lub jednym z wielu objawów choroby. Występuje u około $40 \%$ pacjentów, a napady padaczkowe zazwyczaj słabo reagują na stosowane leczenie farmakologiczne. Około $90 \%$ ME to padaczki lekooporne [1]. Według niektórych autorów leczenie pierwotnej choroby mitochondrialnej mogłoby być bardziej skuteczną strategią niż stosowanie leków przeciwpadaczkowych [3,4].

Częstość ME zależy od rodzaju stwierdzanej mutacji i jest wyższa w populacji dzieci i młodzieży niż u dorosłych. W populacji dziecięcej ME najczęściej występuje w chorobach związanych z mutacjami w genomie jądrowym, rzadziej mitochondrialnym. $\mathrm{U}$ dorosłych jest odwrotnie. U dzieci i młodzieży, w przeciwieństwie do dorosłych, napady ogniskowe występują częściej niż uogólnione. 
Padaczka mitochondrialna stanowi szczególne wyzwanie dla neurologów dziecięcych. W badaniu retrospektywnym El Sabbagha i wsp. [4] (16-letnia obserwacja grupy dzieci i młodzieży z MD i padaczką) pierwsze napady padaczkowe pojawiały się między 1. dniem życia a 20. rokiem życia, ze szczytem zachorowania w 1. roku życia. Napady padaczkowe były początkową manifestacją MD u 17,5\% pacjentów, u pozostałych występowanie pierwszych napadów było poprzedzone opóźnieniem rozwoju psychoruchowego, kwasicą mleczanową lub innymi objawami neurologicznymi (ataksją, objawami piramidowymi, pozapiramidowymi, oftalmoplegią, retinopatią, głuchotą lub neuropatią). Wszystkie typy napadów padaczkowych, oprócz napadów zgięciowych, stanowiły znaczący problem leczniczy. Pojawienie się pierwszych napadów u ponad połowy pacjentów (57\%) przebiegało w sposób bardzo gwałtowny, najczęściej objawiając się długotrwającym stanem padaczkowym. Dołączenie się napadów padaczkowych do innych objawów MD znacznie pogarszało rokowanie. Śmiertelność podczas choroby w cytowanym badaniu wynosiła 45\%; połowa pacjentów zmarła w ciągu 9 miesięcy od rozpoznania padaczki [4].

Odsetek dorosłych pacjentów z ME jest niższy niż w populacji dzieci i młodzieży. W badaniu Finsterera i Mahjouba [5] przeprowadzonym w populacji dorosłych z MD odsetek ten wynosił 14\%, a w badaniu Whittakera i wsp. - 23,1\% [6]. Średni wiek chorego przy wystąpieniu padaczki wynosił 29,4 roku [6].

\section{CHARAKTERYSTYCZNE CECHY PADACZKI W POSZCZEGÓLNYCH ZESPOLACH}

Choroby mitochondrialne, niezależnie od stwierdzanej mutacji, mogą mieć bardzo różnorodne oblicze. Obraz kliniczny jest determinowany przez kilka czynników: stwierdzaną mutację, ilość zmutowanego mtDNA czy zapotrzebowanie na energię w poszczególnych tkankach, które może się różnić między innymi w zależności od wieku [7]. Łagodne i ciężkie postaci MD mogą współistnieć w obrębie jednej rodziny.

Niektóre MD spełniają kryteria zespołu chorobowego. Do najbardziej znanych zespołów należą zespół Leigha, zespół MERRF i zespół MELAS.

\section{Zespól Leigha}

Zespół Leigha to podostra martwicza encefalomielopatia związana z mutacjami w genach koniecznych do prawidłowego funkcjonowania mitochondriów. Znanych jest ponad 75 genów, zlokalizowanych zarówno w DNA mitochondrialnym (mtDNA), jak i DNA jądra komórkowego (nDNA), których mutacja może doprowadzić do choroby [8]. Najczęściej obserwuje się zaburzenia pracy kompleksu I łańcucha oddechowego, rzadziej kompleksu IV oraz kompleksów II, III i zaburzeń struktury koenzymu Q10 [9, 10]. Kryterium rozpoznania zespołu Leigha stanowią objawy zajęcia jąder podstawy, opóźniony rozwój psychomotoryczny oraz podwyższone stężenie kwasu mlekowego w płynie mózgowo-rdzeniowym i/lub surowicy krwi. Zajęcie jąder podstawy powinno być potwierdzone w badaniu rezonansu magnetycznego (MRI, magnetic resonance imaging). Charakterystycznym obrazem są symetryczne, hiperintensywne, zmiany w sekwencji T2-zależenej, najczęściej obserwowane w skorupie i substancji czarnej, ale mogą występować również w jądrze czerwiennym, móżdżku i rdzeniu przedłużonym [8, 11]. W przypadku niestwierdzenia wszystkich kryteriów rozpoznaje się zespół Leigh-podobny (ang. Leigh-like). Początkowo rozwój psychomotoryczny dzieci z zespołem Leigha przebiega prawidłowo. Objawy pojawiają w wieku wczesnodziecięcym, często poprzedzone infekcją. W przebiegu choroby obserwuje się regres rozwoju, hipotonię, dystonię, ataksję, oczopląs oraz problemy podczas karmienia [11]. U połowy pacjentów występują problemy z oddychaniem spowodowane hiperwentylacją lub centralną hipowentylacją. Napady padaczkowe występują u 40\% pacjentów z zespołem Leigha [12]. Obserwuje się zarówno napady pierwotnie uogólnione toniczno-kloniczne, napady zgięciowe [13], jak i napady ogniskowe. Choroba prowadzi do zgonu zazwyczaj w ciągu 2 lat od pojawienia się objawów. Za złe rokowniczo uznaje się wczesny początek choroby (przed 6. mies. życia), napady padaczkowe w obrazie klinicznym, mutacje w obrębie SLC19A3 i SURF1 oraz zmiany radiologiczne w pniu mózgu [12]. 


\section{Zespół MERRF}

Kolejnym zespołem przebiegającym z padaczką jest zespół MERRF (myoclonic epilepsy with ragged red fibers), tj. padaczka miokloniczna z czerwonymi poszarpanymi włóknami. Napady padaczkowe są najczęstszym objawem tego zespołu. Oprócz napadów padaczkowych częstymi objawami są mioklonie, ataksja, niedosłuch odbiorczy, miopatia, neuropatia obwodowa, nietolerancja wysiłku, atrofia nerwu wzrokowego, deficyty poznawcze i niski wzrost. W niektórych przypadkach obserwuje się kardiomiopatię, retinopatię barwnikową, objawy piramidowe, oftalmoplegię lub mnogie tłuszczaki [14]. Najczęstszym typem napadów padaczkowych są uogólnione napady miokloniczne [15]. Inne rodzaje napadów opisywane w MERRF to ogniskowe miokloniczne, ogniskowe atoniczne, ogniskowe kloniczne, uogólnione toniczno-kloniczne, uogólnione atoniczne, uogólnione miokloniczno-atoniczne, typowe napady nieświadomości oraz miokloniczne napady nieświadomości. Mioklonie w MERRF mogą być ciągłe lub sporadyczne, foto- lub bodźcowrażliwe. Należy wziąć pod uwagę fakt, że niekiedy mioklonie w tym zespole mogą mieć charakter niepadaczkowy [15].

\section{Zespół MELAS}

Encefalomiopatia mitochondrialna z kwasicą mleczanową i epizodami udaropodobnymi (MELAS, mitochondrial myopathy, encephalopathy, lacticacidosis, stroke-like episodes) jest jedną z najczęściej występujących chorób mitochondrialnych dziedziczonych w linii matczynej. Za kluczową dla patogenezy zespołu MELAS uważa się mutację m.3243A > G obecną u $80 \%$ pacjentów [16]. Patognomoniczne dla MELAS są epizody podobne do udarów, otępienie, padaczka, kwasica mleczanowa, miopatia, nawracające bóle głowy, cukrzyca, niedosłuch odbiorczy oraz niedobór wzrostu. Objawy w $65-75 \%$ przypadków pojawiają się przed 20. rokiem życia, przy czym jedynie $5-8 \%$ przed ukończeniem 2 lat. W 1-6\% objawy pojawiają się po 40. roku życia $[17,18]$. W 2012 roku zaproponowano nowe kryteria diagnostyczne MELAS, na podstawie których chorobę można rozpoznać, jeśli wystąpią co najmniej dwa objawy z kategorii
A, obejmującej bóle głowy z wymiotami, napady padaczkowe, ślepotę korową i zmiany ogniskowe w badaniach neuroobrazowych, oraz dwa objawy z kategorii B, obejmującej wysokie stężenie kwasu mlekowego w osoczu lub płynie mózgowo-rdzeniowym, mutacje genów związanych z MELAS i nieprawidłowy obraz mitochondriów w biopsji mięśnia [17].

Napady padaczkowe występują u 71-96\% chorych z zespołem MELAS $[17,19]$. W obrazie dominują napady ogniskowe, ale obecne są również napady pierwotnie uogólnione. Mogą się manifestować jako epizody podobne do udaru, niezależnie od niego lub być czynnikiem prowokującym jego wystąpienie [20].

\section{Inne zespoly}

Należy zwrócić uwagę także na inne choroby mitochondrialne, w przebiegu których mogą wystąpić napady padaczkowe, ale nie są one zazwyczaj typową manifestacją kliniczną tych zespołów.

Zespół Kearnsa-Sayre'a jest chorobą mitochondrialną, która objawia się głównie postępującą oftalmoplegią zewnętrzną, zwyrodnieniem barwnikowym siatkówki i zaburzeniami przewodzenia w sercu. Do dodatkowych, rzadziej występujących, objawów należą również napady padaczkowe, ataksja móżdżkowa i mioklonie.

Kolejną chorobą mitochondrialną, która może się klinicznie objawiać między innymi napadami padaczkowymi, jest zespół NARP (neurogenic myopathy, ataxia, retinitis pigmentosa) - neurogenna miopatia z ataksją i zwyrodnieniem barwnikowym siatkówki. Główne objawy to zwyrodnienie barwnikowe siatkówki, neuropatie i ataksja. Padaczka występuje częściej u pacjentów z wczesnym początkiem choroby, natomiast jeśli początek choroby miał miejsce u osób dorosłych, to padaczka jest rzadkim objawem [21].

Padaczka może wystąpić także w dziedzicznej neuropatii nerwu wzrokowego Lebera, zespole leukoencefalopatii z zajęciem pnia mózgu i rdzenia kręgowego oraz podwyższonym stężeniem mleczanu (LBSL, leukoencephalopathy with brainstem and spinal cord involvement and lactate elevation) czy w ataksji rdzeniowo-móżdżkowa o początku 
w okresie niemowlęcym (IOSCA, infantile-onset spinocerebellar ataxia).

\section{LECZENIE PRZECIWPADACZKOWE}

Leczenie farmakologiczne ME zasadniczo nie różni się od leczenia padaczki innej niż mitochondrialna, ale należy uwzględnić pewne odstępstwa. Publikowane są kazuistyczne opisy przypadków osiągnięcia dobrej kontroli napadów padaczkowych dzięki zastosowaniu wybranych leków przeciwpadaczkowych, jednak ogromna niejednorodność grupy pacjentów z ME utrudnia interpretację takich doniesień [3]. Podstawą leczenia ME powinny być leki o niskim potencjale toksyczności wobec mitochondriów, na przykład lamotrygina (LTG, lamotrygine), lewetyracetam (LEV, levetiracetam), gabapentyna (GBP, gabapentin), zonisamid (ZNS, zonisamide), kanabidiol (CBD, cannabidiol) [13]. Z kolei leki o wysokim potencjale toksyczności dla mitochondriów, na przykład kwas walproinowy (VPA, valproic acid), karbamazepinę (CBZ, carbamazepine), fenytoinę (PHT, phenytoin), fenobarbital (PB, phenobarbital) czy retigabinę (RTG, retiagabine), należy stosować ze szczególną ostrożnością.

Szczególną ostrożność trzeba również zachować, podejmując decyzję o włączeniu preparatów VPA - nie tylko u pacjentów z rozpoznaniem MD, ale również w przypadku podejrzenia ME. Preparaty VPA mogą odgrywać kluczową rolę w przyspieszeniu niewydolności wątroby, choć mechanizm takiego działania pozostaje niejasny. Szczególnie narażoną grupą na wystąpienie niewydolności wątroby są pacjenci z mutacją w genie POLG1. W grupie dzieci z objawami przypominającymi zapalenie mózgu ewoluującymi do encefalopatii z zajęciem wątroby należy przeprowadzić analizę gamma-1 polimerazy (POLG1, polymerase subunit gamma), nawet jeśli MRI mózgu, aktywność łańcucha oddechowego i ilość mtDNA w mięśniach szkieletowych pozostają prawidłowe [13]. Niektórzy autorzy postulują nawet przesiewowe badanie dzieci pod kątem tej mutacji przed włączeniem do leczenia VPA [22]. W przypadku konieczności podania leków dożylnie, na przykład z powodu stanu padaczkowego, zaleca się rozpocząć lecze- nie od podania benzodiazepiny, a następnie LEV, PHT, lakozamidu (LCM, lacosamide) lub PB [23].

Nie u wszystkich pacjentów z ME uzyskuje się wystarczającą kontrolę napadów padaczkowych po zastosowaniu leków o niskim potencjale toksyczności wobec mitochondriów. Stosowanie w ME leków o wysokim poziome toksyczności dla mitochondriów wiąże się zawsze z ryzykiem, choć indywidualna tolerancja substancji jest bardzo zmienna, a efekt jednostkowy — niemożliwy do przewidzenia. Bezwzględne unikanie wszystkich potencjalnie toksycznych leków niesie ryzyko pozbawienia pacjenta możliwego skutecznego leczenia. Leki przeciwpadaczkowe o wysokim poziomie toksyczności dla mitochondriów mogą być toksyczne dla niektórych chorych, a u innych nie powodować działań niepożądanych [23]. W sytuacji gdy leki o niskim potencjale toksyczności są nieskuteczne, można rozważyć zastosowanie leku potencjalnie toksycznego dla mitochondriów.

\section{Leczenie alternatywne}

W przypadkach padaczki lekoopornej należy rozważyć włączenie diety ketogennej. Konsekwencją jej stosowania może być modyfikacja ekspresji genów związanych z metabolizmem tlenowym, zmniejszenie stresu oksydacyjnego, zahamowanie glikolizy, zwiększenia rezerw energetycznych, stabilizacja synaps oraz spowolnienie procesu epileptogenezy [24]. Doniesienia dotyczące efektów zastosowania diety ketogennej w MD są sprzeczne. W pracy El Sabbagha i wsp. [4] u żadnego z pacjentów stosujących dietę ketogenną nie uzyskano istotnego zmniejszenia częstości napadów padaczkowych. Z kolei w badaniu Kanga i wsp. [24] z udziałem 14 pacjentów wykazano, że zastosowanie diety ketogennej u 10 z nich ograniczyło częstość występowania napadów padaczkowych o ponad $50 \%$, a u 7 pacjentów napady padaczkowe ustąpiły. Korzyści ze stosowania tej diety w ME podkreślali również Lee i wsp. [25], w których badaniu aż u 75\% pacjentów leczonych dietą ketogenną uzyskano zmniejszenie liczby napadów padaczkowych. 


\section{Leczenie przyczynowe}

W przypadku MD, u podłoża których leżą zaburzenia w syntezie koenzymu Q10, należy zastosować jego suplementację. Doustna suplementacja koenzymu Q10 u dzieci powinna wynosić 10-30 mg/ /kg mc./dobę, a u dorosłych 1200-3000 mg/dobę [26]. Najlepsza odpowiedź pojawia się u pacjentów z mutacją w genie COQ2, szczególnie z neurologiczną i nefrologiczną manifestacją choroby.

Kolejna grupa chorób, w których można zastosować leczenie przyczynowe, to MD spowodowane mutacjami w genach kodujących flawoproteiny będące składową kompleksu I łańcucha oddechowego. W mutacji ACAD9 poprawę kliniczną może przynieść suplementacja ryboflawiny (witaminy B2).

U pacjentów z zespołem Leigha związanej z mutacją w genie PDH E1- $\alpha$ uzyskano zmniejszenie liczby uogólnionych napadów toniczno-klonicznych po doustnej podaży sodku pirogronianu w dawce $0,5 \mathrm{~g} / \mathrm{kg} \mathrm{mc}$./dobę [19].

W piśmiennictwie pojawiają się także doniesienia o zastosowaniu innych witamin, przeciwutleniaczy, alternatywnych źródeł energii, a także koenzymów w leczeniu MD, ale - jak dotąd - nie ma rozstrzygających danych na temat skuteczności takiego postępowania $[13,27]$.

\section{PODSUMOWANIE}

Padaczka mitochondrialna może być jedynym objawem MD lub jednym z jej wielu objawów; występuje częściej w populacji dzieci i młodzieży niż w populacji dorosłych. Uzyskanie satysfakcjonującej kontroli napadów padaczkowych nie zawsze jest łatwym do osiągnięcia celem. Podejmując się leczenia padaczki u chorego z MD, należy unikać leków o wysokim potencjale toksyczności dla mitochondriów, w szczególności preparatów VPA.

\section{PIŚMIENNICTWO}

1. Schaefer A, Lim A, Gorman G. Epidemiology of mitochondrial disease. In: Mancuso M, Klopstock T. ed. Diagnosis and management of mitochondrial disorders. Springer, Cham 2019: 63-79.

2. Jameson E, Morris A. Mitochondrial disease - a review. Paediatr Child Health. 2011; 21(2): 80-83, doi: 10.1016/j.paed.2010.09.008.

3. Rahman S. Advances in the treatment of mitochondrial epilepsies. Epilepsy Behav. 2019; 101(Pt B): 106546, doi: 10.1016/j. yebeh.2019.106546, indexed in Pubmed: 31677997.
4. El Sabbagh S, Lebre AS, Bahi-Buisson N, et al. Epileptic phenotypes in children with respiratory chain disorders. Epilepsia. 2010 51(7): 1225-1235, doi: 10.1111/j.1528-1167.2009.02504.x, indexed in Pubmed: 20196775.

5. Finsterer J, Mahjoub SZ. Presentation of adult mitochondrial epilepsy. Seizure. 2013; 22(2): 119-123, doi: 10.1016/j.seizure.2012.11.005, indexed in Pubmed: 23200763.

6. Whittaker RG, Devine HE, Gorman GS, et al. Epilepsy in adults with mitochondrial disease: a cohort study. Ann Neurol. 2015; 78(6): 949-957, doi: 10.1002/ana.24525, indexed in Pubmed: 26381753

7. Uziel G, Moroni I, Lamantea E, et al. Mitochondrial disease associated with the T8993G mutation of the mitochondrial ATPase 6 gene: a clinical, biochemical, and molecular study in six families. J Neurol Neurosurg Psychiatry. 1997; 63(1): 16-22, doi: 10.1136/ /jnnp.63.1.16, indexed in Pubmed: 9221962.

8. Lake NJ, Compton AG, Rahman S, et al. Leigh syndrome: one disorder, more than 75 monogenic causes. Ann Neurol. 2016; 79(2): 190-203, doi: 10.1002/ana.24551, indexed in Pubmed: 26506407.

9. Ma YY, Wu TF, Liu YP, et al. Genetic and biochemical findings in Chinese children with Leigh syndrome. J Clin Neurosci. 2013; 20(11): 1591-1594, doi: 10.1016/j.jocn.2013.03.034, indexed in Pubmed: 23953430.

10. Lake NJ, Bird M, Isohanni P, et al. Leigh syndrome. J Neuropathol Exp Neurol. 2015; 74(6): 482-492, doi: 10.1097/nen.000000 0000000195, indexed in Pubmed: 25978847

11. Baertling F, Wagner M, Brunet $T$, et al. A guide to diagnosis and treatment of Leigh syndrome. J Neurol Neurosurg Psychiatry. 2014; 85(3): 257-265, doi: 10.1136/jnnp-2012-304426, indexed in Pubmed: 23772060.

12. Sofou K, De Coo IFM, Isohanni P, et al. A multicenter study on Leigh syndrome: disease course and predictors of survival. Orphanet J Rare Dis. 2014; 9: 52, doi: 10.1186/1750-1172-9-52, indexed in Pubmed: 24731534.

13. Finsterer J, Mahjoub SZ. Mitochondrial epilepsy in pediatric and adult patients. Acta Neurol Scand. 2013; 128(3): 141-152, doi: 10.1111/ane.12122.

14. Domańska M, Sitek EJ, Schinwelski M, et al. Cognitive functions in myoclonic epilepsy with ragged red fibres - a case report. J Epileptol. 2015 Jun 26. ; 23(1): 69-74, doi: 10.1515/joepi-2015-0026.

15. Finsterer J, Zarrouk-Mahjoub S. Management of epilepsy in MERRF syndrome. Seizure. 2017; 50: 166-170, doi: 10.1016/j. seizure.2017.06.010, indexed in Pubmed: 28686997.

16. Debray FG, Lambert M, Chevalier I, et al. Long-term outcome and clinical spectrum of 73 pediatric patients with mitochondrial diseases. Pediatrics. 2007; 119(4): 722-733, doi: 10.1542/peds.20061866, indexed in Pubmed: 17403843.

17. Yatsuga S, Povalko N, Nishioka J, et al. Taro Matsuoka for MELAS Study Group in Japan. MELAS: a nationwide prospective cohort study of 96 patients in Japan. Biochim Biophys Acta. 2012; 1820(5): 619-624, doi: 10.1016/j.bbagen.2011.03.015, indexed in Pubmed: 21443929.

18. Sproule DM, Kaufmann P. Mitochondrial encephalopathy, lactic acidosis, and strokelike episodes: basic concepts, clinical phenotype, and therapeutic management of MELAS syndrome. Ann NY Acad Sci. 2008; 1142: 133-158, doi: 10.1196/annals.1444.011, indexed in Pubmed: 18990125.

19. Hirano M, Pavlakis SG. Mitochondrial myopathy, encephalopathy, lactic acidosis, and strokelike episodes (MELAS): current concepts. J Child Neurol. 1994; 9(1): 4-13, doi: 10.1177/088307389400900102, indexed in Pubmed: 8151079

20. Finsterer J, Zarrouk-Mahjoub S. Focal and generalized seizures may occur in mitochondrial encephalomyopathy, lactic acidosis, 
and stroke-like episodes (MELAS) patients. J Child Neurol. 2015; 30(11): 1553-1554, doi: 10.1177/0883073814567539, indexed in Pubmed: 25637648.

21. Finsterer J, Zarrouk Mahjoub S. Epilepsy in mitochondrial disorders. Seizure. 2012; 21 (5): 316-321, doi: 10.1016/j.seizure.2012.03.003, indexed in Pubmed: 22459315.

22. Finsterer J, Zarrouk Mahjoub S. Epilepsy in mitochondrial disorders. Seizure. 2012; 21 (5): 316-321, doi: 10.1016/j.seizure.2012.03.003, indexed in Pubmed: 22459315.

23. Finsterer J, Scorza FA. Effects of antiepileptic drugs on mitochondrial functions, morphology, kinetics, biogenesis, and survival. Epilepsy Res. 2017; 136: 5-11, doi: 10.1016/j.eplepsyres.2017.07.003, indexed in Pubmed: 28732239.
24. Kang HC, Lee YM, Kim HD. Mitochondrial disease and epilepsy. Brain Dev. 2013; 35(8): 757-761, doi: 10.1016/j.braindev.2013.01.006, indexed in Pubmed: 23414619

25. Lee YM, Kang HC, Lee JS, et al. Mitochondrial respiratory chain defects: underlying etiology in various epileptic conditions. Epilepsia. 2008; 49(4): 685-690, doi: 10.1111/j.1528-1167.2007.01522.x, indexed in Pubmed: 18266755.

26. Rahman S, Clarke CF, Hirano M. 176th ENMC International Workshop: diagnosis and treatment of coenzyme $Q_{10}$ deficiency. Neuromuscul Disord. 2012; 22(1): 76-86, doi: 10.1016/j. nmd.2011.05.001, indexed in Pubmed: 21723727.

27. Rahman S. Pathophysiology of mitochondrial disease causing epilepsy and status epilepticus. Epilepsy Behav. 2015; 49: 71-75, doi: 10.1016/j.yebeh.2015.05.003, indexed in Pubmed: 26162691. 